\title{
Electronic message ataxia in multiple system atrophy
}

Figure Patient's electronic communication

A

"Ok,,,,,gRaciAS,,puedO. TomAr Remedio, yA nbo ME mUevO. Yy Ccasi no controlo. ExtreMidadEs".

"NO se. Si. Puedes sugerirme. ALgO. Si creeS"

"GRacias,,,,favOr.MaaNdamnE recetA pOR estA viA".

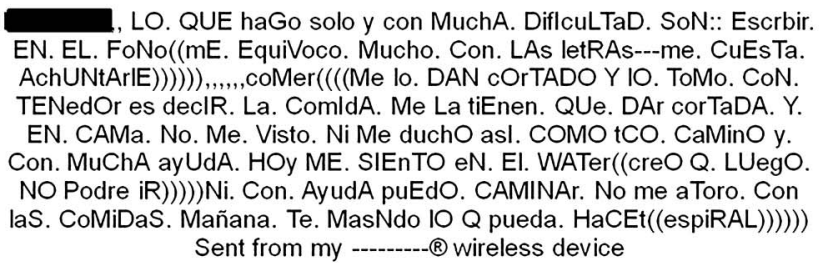

B

"Ok, $,{ }_{, \ldots}, \mathrm{tHanKS}$, , I CaN. TaKe the Medication, I caN't mOvE any more. And and Almost can't control. LiMbS".

"I dOn't know. If. You can suggest. SOmetHing. If you thinK"

“THanks,,,, pleAse.SeeNd mE prescription vlA e-malL”.

WHAT. I CAn do by my self and with a LOT of. TrOUBIE. IS:: Writing ON. THE. PhoNe ( (I mAke. A Lot. Of TyPOs--have.TrOuBle. To gEt the rlGht

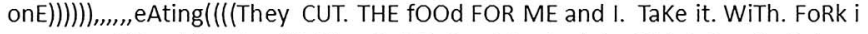
mean. THey have to cUt. The. FoOD. For. Me. And. In. BEd. I. Don't. Get. Dressed Or bAthe. OR WAIK either and. With. A IOT of hEIP. AS of now. I CAN USE. The. TOllet((I thiNK. LAter. I WON’T Be Able tO) )))) )Even. With HeLp. I AM not aBLe to walk. I don't cHoke. On. FoOD. Tomorrow. I will seNd. You. What. I caN Do ((SpiRAL drawing))))))

Capital letters are generated on this particular device by increasing pressure on keys and demonstrate an unusual manifestation of ataxia. (A) Original; (B) approximate translation into English with formatting preserved.

A 65-year-old patient with 5 years of progressive ataxia and dysarthria developed problems typing on his wireless electronic device when communicating with his consultant neurologist. Typing on his home computer was not affected. He was wheelchair-bound due to severe autonomic dysfunction resulting in syncope. Cognition was intact. There was no relevant family history and an extensive workup was negative. He was diagnosed with probable multiple system atrophy-cerebellar type. ${ }^{1,2}$ In the past year, he developed problems with typing on his wireless device (figure) with random use of capital letters and punctuation, which may be a manifestation of his severe ataxia.

Marcelo Miranda, MD, Ruth H. Walker, MBChB, PhD, FAAN, M.L. Bustamante, MD, PhD

From the Department of Neurology (M.M.), Clinica Las Condes, Santiago, Chile; Department of Neurology (R.H.W.), James J. Peters Veterans Affairs Medical Center, Bronx, NY; and the Faculty of Medicine (M.L.B.), University of Chile, Santiago.

Author contributions: Dr. Miranda: study concept and design, acquisition of data, analysis and interpretation. Dr. Walker: critical revision of the manuscript for important intellectual content. Dr. Bustamante: critical revision of the manuscript for important intellectual content.

Study funding: No targeted funding reported.

Disclosure: The authors report no disclosures relevant to the manuscript. Go to Neurology.org for full disclosures.

Correspondence to Dr. Miranda: marcelomirandac@gmail.com

1. Stefanova N, Bucke P, Duerr S, Wenning GK. Multiple system atrophy: an update. Lancet Neurol 2009;8:1172-1178.

2. Gilman S, Low PA, Quinn N, et al. Consensus statement on the diagnosis of multiple system atrophy. J Neurol Sci 1999;163: 94-98. 


\title{
Neurology
}

\author{
Electronic message ataxia in multiple system atrophy \\ Marcelo Miranda, Ruth H. Walker and M.L. Bustamante \\ Neurology 2014;83;1677 \\ DOI 10.1212/WNL.0000000000000938
}

This information is current as of October 27, 2014

\section{Updated Information \& Services}

References

Subspecialty Collections

Permissions \& Licensing

Reprints including high resolution figures, can be found at: http://n.neurology.org/content/83/18/1677.full

This article cites 2 articles, 0 of which you can access for free at: http://n.neurology.org/content/83/18/1677.full\#ref-list-1

This article, along with others on similar topics, appears in the following collection(s):

Gait disorders/ataxia

http://n.neurology.org/cgi/collection/gait_disorders_ataxia

Multiple system atrophy

http://n.neurology.org/cgi/collection/multiple_system_atrophy

Information about reproducing this article in parts (figures,tables) or in its entirety can be found online at:

http://www.neurology.org/about/about_the_journal\#permissions

Information about ordering reprints can be found online:

http://n.neurology.org/subscribers/advertise

Neurology ${ }^{\circledR}$ is the official journal of the American Academy of Neurology. Published continuously since 1951, it is now a weekly with 48 issues per year. Copyright (C) 2014 American Academy of Neurology. All rights reserved. Print ISSN: 0028-3878. Online ISSN: 1526-632X.

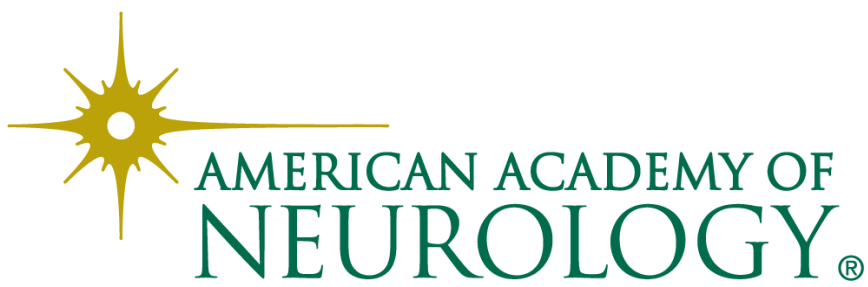

